\title{
Genius Loci: Place as a Mean to Develop Inter and Transdisciplinary Skills for Architecture Students
}

\author{
By Karine Dupré* \& Anke Vrijs ${ }^{*}$
}

The French government has a long tradition of supporting the Arts as well as supporting collaborations between artists and architects. In the case of architecture education, expected skills and competencies are by nature multidisciplinary, as the practitioner never works alone but is always in contact with other professionals of the built environment such as engineers, planners, and sociologists, for instance. However, it does not mean automatically that courses are multidisciplinary or even trans or interdisciplinary. This study is based on a ten year land art workshop organized for second year architecture students and questions how inter or transdisciplinary skills for architecture students are developed through experimenting and learning about the relationship between art and the natural environment. Methodologically, the analysis was based on the systematic review of the produced outcomes, and is trying to identify the variable factors that might have influenced them. Findings show that even if the course provides interdisciplinary skills, transdisciplinary features are not really present, unless a real critical reflection is actioned.

\section{Introduction}

The French government has a long tradition of supporting the Arts in the built environment. In 1951, it legislated a law that stated "one percent of the total budget spent for the construction of a new state building (school, university, etc.) will be dedicated to the creation of a contemporary art project to be integrated to the architectural design." After decades of collaborations between artists and architects, further incentives emerged in the 1990s onwards to encourage artistic interventions in natural and urban spaces. This created a new opportunity in terms of scale and network as it involved larger territories and new professionals such as city planners, urban designers and landscape architects. ${ }^{2}$ The legacy of this multidisciplinarity is visible today throughout France. It ranges from highly contested projects (e.g. the Columns "Les deux Plateaux" of Daniel Buren in Paris, 1986, Figure 1) to those well accepted such as Pourtales Park or artwork on the tram in Strasbourg (Figure 2). For the latter, artists were asked to establish a tight relationship with nature through their creation. In both cases, the artists were supposed to interact with a specific environment having not only an urban, architectural, natural or social but also an emotional content.

\footnotetext{
${ }^{*}$ Associate Professor, Griffith University, Australia.

${ }^{\ddagger}$ Associate Professor, Strasbourg National Institute of Applied Sciences, France.

1. Legifrance, legifrance.gouv.fr. [Accessed November 25, 2017].

2. Serge Lemoine, L'Art dans le Paysage du Tramway d' Orléans (Paris: Editions des Musées Nationaux, 2002).
} 


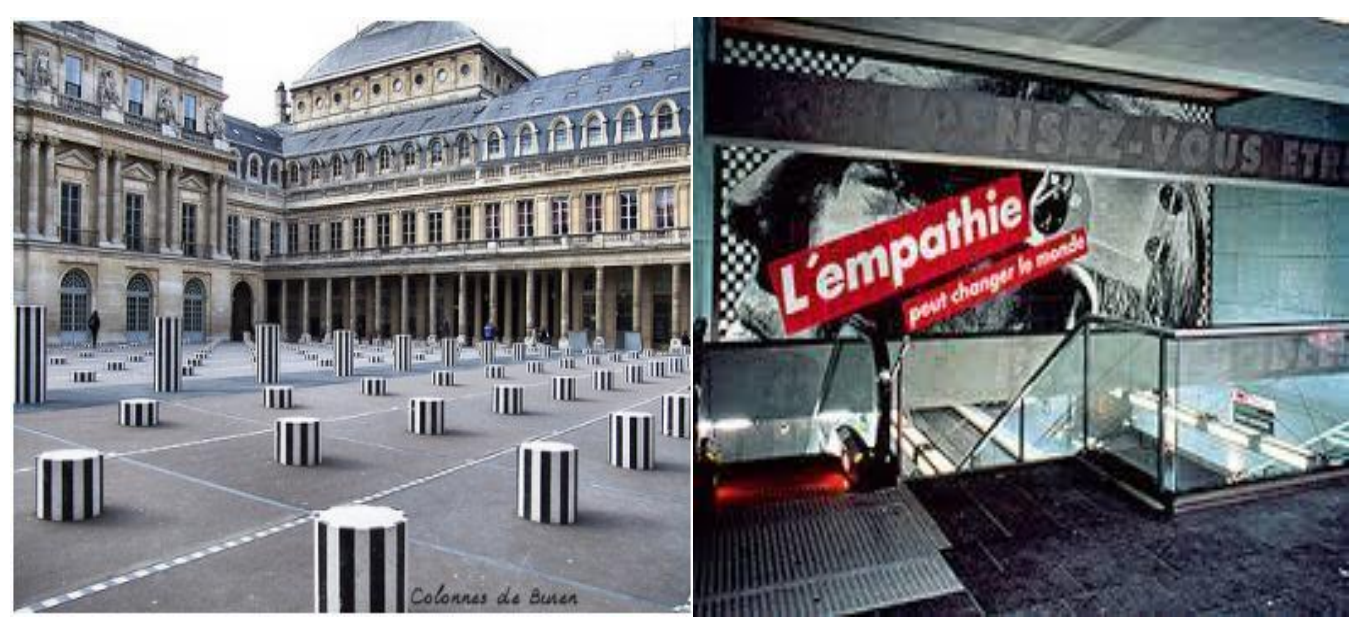

Figures 1 and 2. (left) "Les deux Plateaux" of Daniel Buren in Paris, 1986 (right) Artwork on the Tram in Strasbourg, 1994

Source: (left) blogs.parisnanterre.fr. [Accessed 11/06/2018.] (right) http://publicartmuseum. net/wiki/L\%27empathie_peut_changer_le_monde_(Barbara_Kruger). [Accessed 11/06/2018.]

This study is based on a ten year land art workshop organized for second year architecture students in the forest of Brumath, a small city located $20 \mathrm{~km}$ north of Strasbourg (France). It documents the different processes through which the architecture students developed their work, from revealing the genius loci of the place to the final exhibition of their designs. In this research, we question how inter or transdisciplinary skills for architecture students are developed through experimenting and learning about the relationship between art and the natural environment.

\section{Methodological Context}

\section{Literature Review}

Although there is a wide consensus on the definition of multidisciplinarity to be understood as 'people from different disciplines working together, each drawing on their discipline knowledge, ${ }^{3}$ scholarship in order to understand the difference between inter and transdisciplinary practices has exploded in the last decades for there is a real interest in better understanding what can be gained from these different approaches. Some works concentrate on the reasons why those concepts emerged and on their meanings, ${ }^{4}$ while others concentrate on defining them.

3. Alexander Jensenius, Disciplinarities: Intra, Cross, Multi, Inter, Trans, http://www.arj. no/2012/03/12/disciplinarities-2/. [Accessed May 20, 2018].

4. Patrick Paul and Gaston Pineau, Transdisciplinarité et Formation (Paris: L'Harmattan, 2005); William Newell, "Decision Making in Interdisciplinary Studies," in Handbook of Decision Making (ed.) G. Morçöl (New York: CRC, 2007).

5. See for example the work of Julie Klein, Interdisciplinarity: History, Theory, and Practice (Detroit: Wayne State University Press, 1990); Jeroen Van Merriënboer and Getrudes Johannes, Training Complex Cognitive Skills: A Four-Component Instructional Design Model for Technical 
Based on the initial works of Stember ${ }^{6}$ who developed intellectual, practical and pedagogical argument for interdisciplinarity, this work uses the following definitions proposed by Jensenius (2018): ${ }^{7}$

- Interdisciplinary: integrating knowledge and methods from different disciplines, using a real synthesis of approaches.

- Transdisciplinary: creating a unity of intellectual frameworks beyond the disciplinary perspectives.

Furthermore, Resweber $(2000)^{8}$ poses that interdisciplinarity raises the fundamental question of the outcomes by processing the unification of knowledge, both subjective and objective, which is also a statement announced by Klein $(1990)^{9}$ and Spelt et al. (2009) ${ }^{10}$ by focusing on the context of higher education, emphasised the increased request from the professional world to develop interdisciplinary skills, with, importantly, the possession of real awareness of the different definitions and processes needed to implement true interdisciplinarity, and a fortiori transdisciplinarity.

In the case of architecture education, expected skills and competencies are by nature multidisciplinary, as the practitioner never works alone but is always in contact with other professionals of the built environment such as engineers, planners, and sociologists, for instance. However it does not mean automatically that teaching is multidisciplinary or even trans or interdisciplinary. The extensive scholarships that have emerged in the last two decades advocating better integrated practices within both the profession and the architecture curriculum, ${ }^{11}$ reflects without any doubt an increased interest in doing so. This trend can also be linked to the rising interest in the employability of architecture graduates in combination due to the global financial crisis, the changes in architecture education, and the increased cost and growing academic accountability. ${ }^{12}$ This is also concomitant

Training (Englewood Cliffs: Educational Technology, 1997); Veronica Boix Mansilla, William C. Miller, William. C. and Howard Gardner, "On Disciplinary Lenses and Interdisciplinary Work," in Interdisciplinary Curriculum: Challenges of Implementation (ed.) S. Wineburg and P. Grossman (New York: Teachers College Press, 2000).

6. Marilyn Stember, "Advancing the Social Sciences through the Interdisciplinary Entreprise," The Social Science Journal 1, no. 28 (1991): 1-14.

7. Jensenius, Disciplinarities: Intra, Cross, Multi, Inter, Trans.

8. Jean-Paul Resweber, Le pari de la transdisciplinarité. Vers l'intégration des savoirs (Paris: L'Harmattan, 2000).

9. Klein, Interdisciplinarity: History, Theory, and Practice.

10. Elisabeth Spelt, Harm J. A. Biemans, Hilde Tobi, Pieternel Luning and Matthijs Mulder, "Teaching and Learning in Interdisciplinary Higher Education: A Systematic Review," Education Psychology Review 21, no. 4 (2009): 365-378.

11. Richard Tucker and Hisham Elkadi, "Teaching in Practice: Work Integrated Design Learning and Practice Readiness for Architecture Students," Proceedings of Association of Architecture Schools of Australasia, AASA (Melbourne Australia, 2011), 341-354; Ali El Hanandeh, Karine Dupré and Benoit Gilbert, "Enriching Architecture Courses with Engineering Knowledge," AAEE 2013 Proceedings (2013); IPENZ, Improving Collaboration between Architects and Engineers (Institution of Professional Engineers New Zealand, 2014) [Accessed August 11, 2015].

12. Gaby Atfield and Kate Purcell, "Graduate Labour Market Supply and Demand: Final Year Students' Perceptions of the Skills they have to Offer and the Skills Employers Seek," Futuretrack 
with structural changes in the built environment industry where sustainable development not only provides new ways of thinking, but has become a real driving economical force. The challenge to promote and adopt sustainable practices and to decrease the rate of natural resources and energy consumption, questions methods and actions, as well as the existing systems, regulations and actors. Toward this end, the built environment industry is also the place where experts in design, construction, and management, are experiencing interdisciplinary engagements. ${ }^{13}$ Yet literature is very much focused on the architectural sciences stream and less is known regarding the arts and architecture, which is surprising considering the long intertwined relationships between the two.

In France, architecture education is part of a long governmental institutional tradition (Ecole des Beaux-Arts in Paris), traditionally along with drawing and sculpture, that dates back to the $17^{\text {th }}$ century when it separated from engineering. ${ }^{14}$ The education was heavily based on classical arts and architecture from Ancient Greek and Roman cultures, as well as on apprenticeship, where teachers and more experienced students trained new students, who, in turn, would take over the training of new cohorts. An important pedagogical element was the design charrette, during which design teams were formed with students of every year of the program, working together intensively to achieve usually the last design project of the most experienced student. Knowledge sharing, co-learning and team management were essential attributes of the design charrette. A major milestone occurred in 1968, when the architecture department was separated from the Beaux-Arts and became a discipline on its own, with independent premises and a redefined curriculum. However the principle of charrette remained strong and continues to this day, as a distinctive feature in the architecture training. Today most architecture curriculum worldwide usually includes 4-5 main streams such as design courses, history and theory courses, sciences and technology courses and communication and elective courses. Art courses are usually included in the communication suite and teach drawing and visual communication skills, as well as a different way to view at the world. Each school of architecture has different emphasis on the number of art courses they teach.

Working Paper 4 (2010); Susan J. Shannon and John Paul Swift, "Employing Graduate Attribute Mapping to Bridge the Divide from Education to Industry," Proceedings of $44^{\text {th }}$ Annual Conference of the Architectural Science Association, ANZASCA (Auckland, NZ: United Institute of Technology, 2010).

13. Guy Tapie, Les Architectes: Mutations d'une Profession. Logiques Sociales (Paris: L'Harmattan, 2000); Yves Dauge, Rapport d'Information Fait au Nom de la Commission des Affaires Culturelles sur les Métiers de l'Architecture. Annexe au Procès-Verbal de la Séance du Sénat du 16 Novembre 2004, http://www.senat.fr/rap/r04-064/r04-0641.pdf. [Accessed August 11, 2015].

14. Christel Frapier, Les Ingénieurs-Conseils dans l'Architecture en France, 1945-1975: Réseaux et Internationalisation du Savoir Technique Volume I: Texte (PhD Thesis, University of Paris I, 2009). 


\section{Methodology}

Based on the overall context, this research is aimed at analysing one art course that has run for ten years under the form of a land art workshop in order to understand how inter and transdisciplinary skills for architecture students were developed through experimenting and learning about the relationship between art and the natural environment.

Methodologically, the analysis was based on the systematic review of the produced outcomes to identify similarities and dissimilarities (Figure 3). The comparison included three criteria for the analysis. The first criterion concerned the broad themes of the outcomes, to evaluate whether there would be recurrent themes and to understand how these themes are disciplinary-bound or not. The second criterion concerns the level of integrated transdisciplinarity that was displayed throughout the making process and the outcome itself. This level was essentially assessed against the set of skills that was required to achieve a satisfying outcome. These skills were communication, conceptualisation, design thinking and process, and construction. The last criterion encompasses the different structural variables that might have had an impact on the outcomes, such as changes in the teaching method and changes that affected the site.

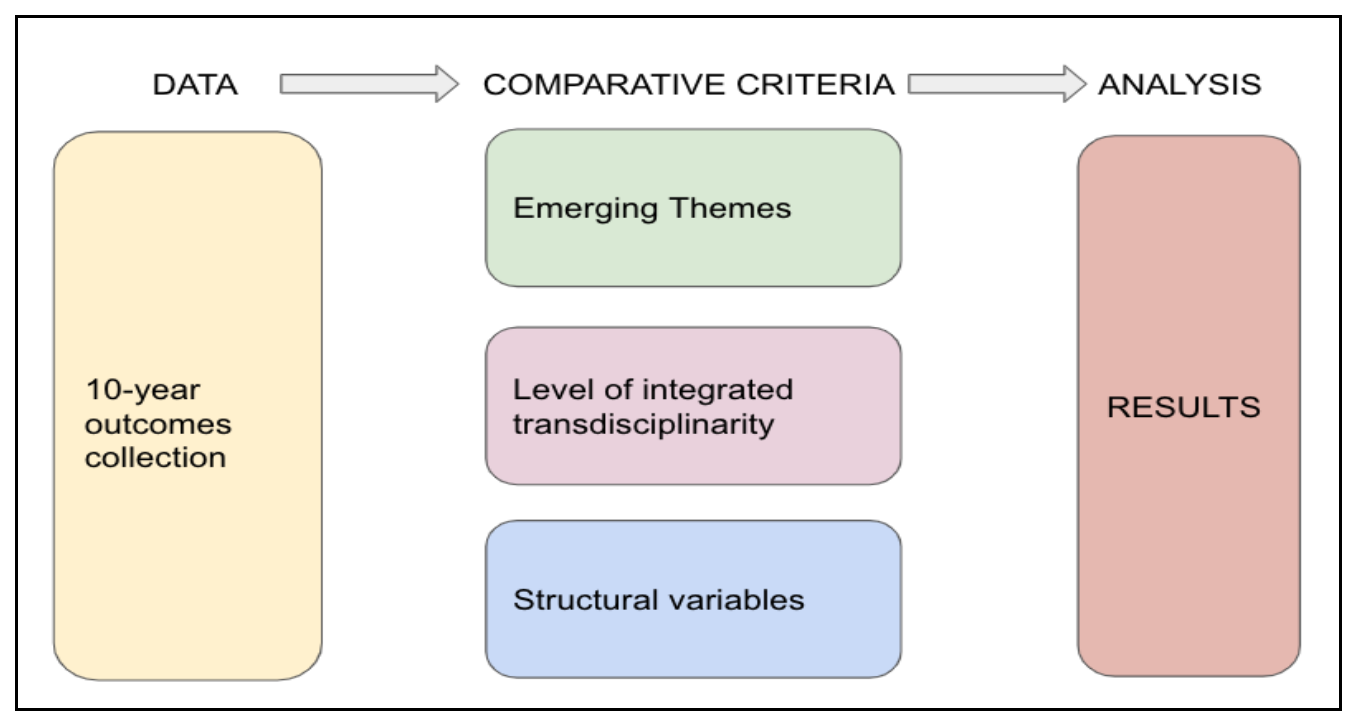

Figure 3. Methodological Diagram

\section{The Workshop Context and Processes}

\section{Context}

The architecture curriculum at the Strasbourg National Institute of Applied Sciences (SNIAS, France) is a professionally accredited program that delivers a master degree after five years of studies. Within this curriculum, 'expression representation' is one of the main streams, gradually introducing students to basic concepts and skills in visual and oral communication and art history to advanced 
competencies. Art is taught during the two first years of the 5-year program, starting by the teaching of drawing and coloring techniques and finishing with a real-life land art workshop, for which students have to deliver three-dimension outcomes in-situ.

This workshop is the fruit of the long-term collaboration between SNIAS and a local authority, Brumath, located $20 \mathrm{~km}$ north of Strasbourg. The project initially originated as one of the responses to a natural disaster that hit the town in December 1999. A cyclone with extreme high speed wind ( $272 \mathrm{~km}$ per hour) had just destroyed more than $60 \%$ of the 460 hectares of forest in only half an hour, which also meant the loss of 15 years of timber exploitation. ${ }^{15}$ At that time, the city authorities and the National Forest Office (Office National des Forêts, ONF) decided to review their policy concerning the use of this forest and the practices of the timber industry. The easy access for the population of Brumath and that of Strasbourg encouraged a different development policy as they had observed that more and more people came to this forest for recreational use. Concomitly, timber production had also dramatically dropped (22\% less than estimated in 2003$)^{16}$ and thus, following this evolution from a timber producing forest to a leisure activities centred area, it was decided to officially reconvert part of the forest for recreational use only. SNIAS was approached in 2008 to develop temporary art installations that would both attract visitors and renew the quality of the experience in the forest.

From the beginning, the project had clear targets. Firstly, it aimed at developing the natural conservation features and heritage by means of information and education in order to stimulate curiosity and recurrent visits. Secondly, to focus the views and minds of the visitors on specific topics such as the regeneration of the forest, information about trees and animals or the Celtic and Roman past of the area. Finally, from a pedagogical point of view, it represented a great opportunity for the students to work with their emotions to enhance the character and culture of an area. Inspired by the work of Norberg Schulz (1979) ${ }^{17}$ who theorised the notion of place into three components, physical location, physical elements (both natural and built) and the qualitative subjective elements of feeling and nature, the land art workshop also aimed at developing awareness of these aspects for the students. Working in-situ for a couple of days in the forest of Brumath, the second year architecture students are annually tasked to design and make art in dialogue with the natural environment or their interpretation of it. The following section presents the processes through which the students develop their work.

15. Office National des Forêts, "Introduction, Aménagement Forestier Forêt Communale de Brumath," (Bas-Rhin, 2014), 2013-2032, https://www.brumath.fr/mairie-brumath/urbanisme-envi ronment-foret-communale.html. [Accessed June 10, 2018].

16. Ibid.

17. Christian Norberg-Schulz, Genius Loci: Towards a Phenomenology of Architecture (New York: Rizzoli, 1979). 


\section{Processes}

The workshop lasts two full days. On Day 1, the students discover the forest and gather some precise, objective and professional input about the specific features of the forest. For example, an ONF warden gives them information about the historical and botanical aspects of the environment. Often the students are surprised to learn that the forest of Brumath has hardly anything "natural". From the Celtic and Roman times, roads were crossing the area and many Celtic tombs (tumuli) are present all around. The forest of Brumath is the result of the numerous elaborations and interventions of mankind like most of the European forests. They also learn that the most dangerous animal of the forest is not larger than $1 \mathrm{~mm}$; a tick transmitting very often the Lyme disease as the Rhine valley is a highly infected region.

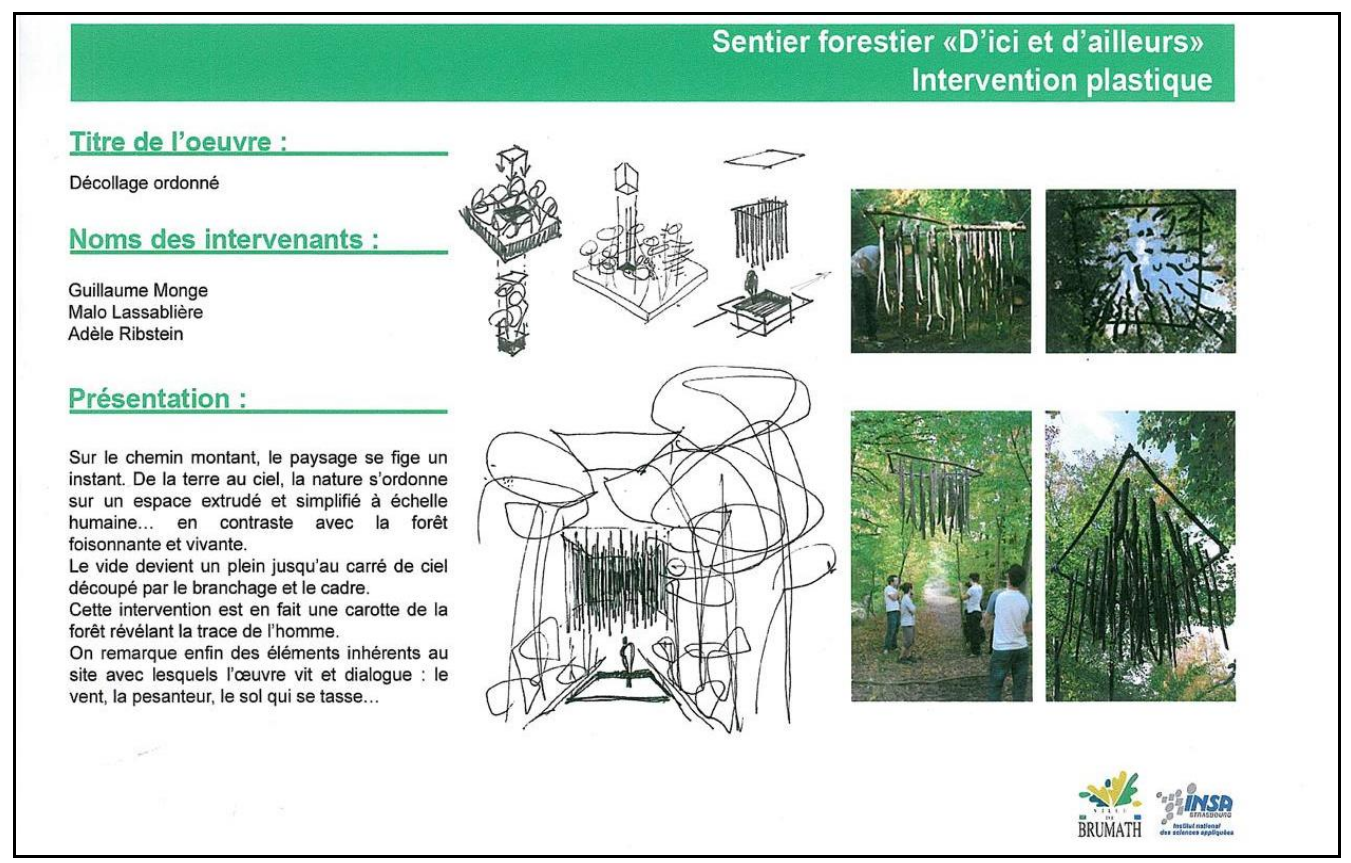

Figure 4. Example of Data Collection by Drawings and Photographs, 2009 Source: Guillaume Monge, Malo Lassablière, Adèle Ribstein.

After this informative session, the students are invited to visit the forest on their own in small groups of 2 or 3 . They explore the place physically and begin to understand its space and the density of the vegetation. They observe the colours, the orientation and configuration of the numerous paths. Then, the students are asked to capture these features and their own sensations in drawings and photographs (Figure 4) to eventually select the particular place to develop their project. They are supposed to focus on one aspect of the chosen place such as the density of the forest, a path leading somewhere, a peculiar point of view, a rotten tree, a hollow or hill for exemple. Somehow the forest whispers the choice of the site to the students' ears, which is rarely the case in the architecture practice where most of the time the site is 'given' to the the architect. The sensory experience of the site gives the first impulsion and allows the students to trust somehow their 
feelings before resolving technical problems. It was noticed that this pedagogical approach is even more efficient for students who have had very little contact with artistic approaches before.

After this subjective phase follows a more rational one. The students start elaborating on their project. It should interact with their chosen site. They are given a list of words to help them to find guidelines for the conception of their work. These words consist of verbs and nouns that pose conditions to the design development because of their meaning (Table 1). On one hand verbs indicate an action, and on the other, the nouns refer to the subjective perception of space.

Table 1. List of Words to Inspire Design Development

\begin{tabular}{|c|c|}
\hline to reveal & hierarchy \\
to dialogue & framework \\
to extend & point of view \\
to oppose & perspective \\
to reflect & staging \\
to elevate & horizon \\
to densify & earth \\
to penetrate & heaven \\
to graft & metamorphosis \\
\hline
\end{tabular}

Using traditional means of architectural expression such as perspective drawings, sketches, plans, cross sections and schemes, the main idea at this point is for the students to conceptualise their project and develop the design proposal. Once this is achieved, the building phase can start.

Day 2 is basically about the construction of the art installations. The city of Brumath lends some gardening tools (rakes, picks, spades and secateurs); SNIAS provides hammers, saws and nails to facilitate more detailed work, whilst students may bring some hemp strings and other biodegradable materials. However their main resource is what they can find in the forest. They may use leaves and wood from fallen trees. They are also encouraged to use the abundantly found twigs from the Prunus Serotina, a plant that has unfortunately invaded the Brumath forest since the 1999 cyclone and has become a serious problem for the regeneration of the forest as it grows easily and very quickly on every open space. During the entire constructing process the teaching team attends to the students and very often the project changes due to the confrontation with the material. It is really a case of learning by doing and experiencing the difference between knowledge and skills.

\section{Results and Discussion}

Within the period of 2008-2018, 157 art installations were produced with the same teaching leadership and course convenor, who is an artist as well. The following lines discuss the main emerging elements from the analysis made about the process and the outcomes of the workshop according to our three criteria. 
Theme: The Forest as Inspiration, Genius Loci

Nature as inspiration for artists is not a new finding and many have already written about it. ${ }^{18}$ However, what is interesting here concerns the repetition of the exercise on the same site over a ten-year period and how recurring themes appear when overviewing all the produced projects. Namely they are geometry, anamorphosis, micro or macro scale, perspectives, archetypes (shelters, huts, nests), inventing architecture and the poetic approach. Typically geometrical shapes such as triangles or squares are used to contrast with the natural environment and its organic features (Figure 5). 'Anamorphosis' suggests a playful relationship between the artist and the visitor; basically the artist challenges the spectator to find the right spot from which the work has to be viewed (Figure $6)$.

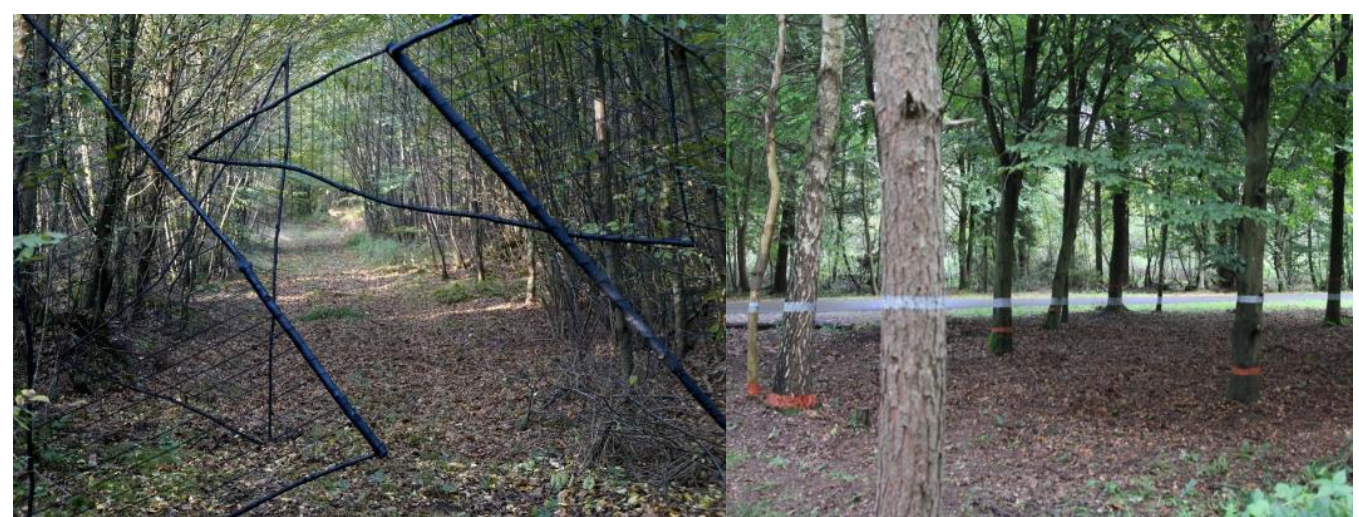

Figures 5 and 6. (left) Examples of Geometry (right) Anamorphosis

Source: (left) Anke Vrijs (right) Michèle Heussner.

In the 'micro macro scale' projects, the students try to emphasize and reveal the visual relationship between small and large scale objects (small pieces of wood and the surrounding forest for example) (Figure 7). By offering the focus on the different scales, they direct the sensory experience from detail to comprehensive understanding of the space. 'Perspective' category is the most popular of the topics chosen by the students. The forest with its increasing density and the fire paths are easily an invitation to work with vanishing points (Figure 8). For 'archetypes', it means that students were using references traditionally associated with forests, such as huts or nests (Figure 9).

18. Gilles Tiberghien, Nature, Art, Paysage (Arles: Actes Sud, 2001); Franck Guêné, De l'Idée Architectural aux Lieux de l'Architecture. L'Approche du Lieu Comme Révélateur de la Nature du Regard de l'Architecture sur le Monde (PhD Thesis, University of Strasbourg, 2009); Hans-Dieter Schaal, Landscape as Inspiration (Berlin: Ernst \& Sohn, 1994); Jean-Noël Bret and Yolaine Escande, Le Paysage, Entre Art et Nature (Rennes: Presses Universitaires, 2017). 


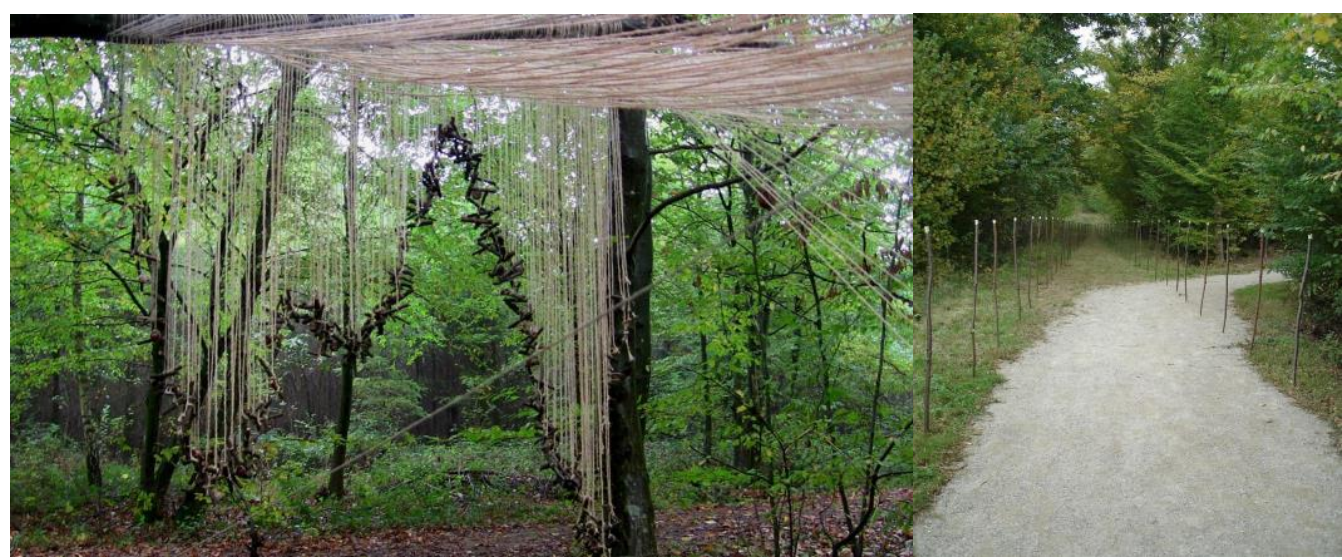

Figures 7 and 8. (left) Micro Macro Scale (right) Perspectives

Source: Anke Vrijs.

'Inventing architecture' often reflected the desire of the students to build up their work with strong architectural models like building arches (Figure 9) or even more complicated structures inspired by tensed fabric (Figure 10). The 'poetic approach' is perhaps the most artistic way of working in the sense that most of the time students freed themselves from references. It resulted in incredible demonstration of meticulous and various projects. Some for example attached hundreds of small red leaves one by one by hairs on twigs or other designed floating triangles (Figure 11).

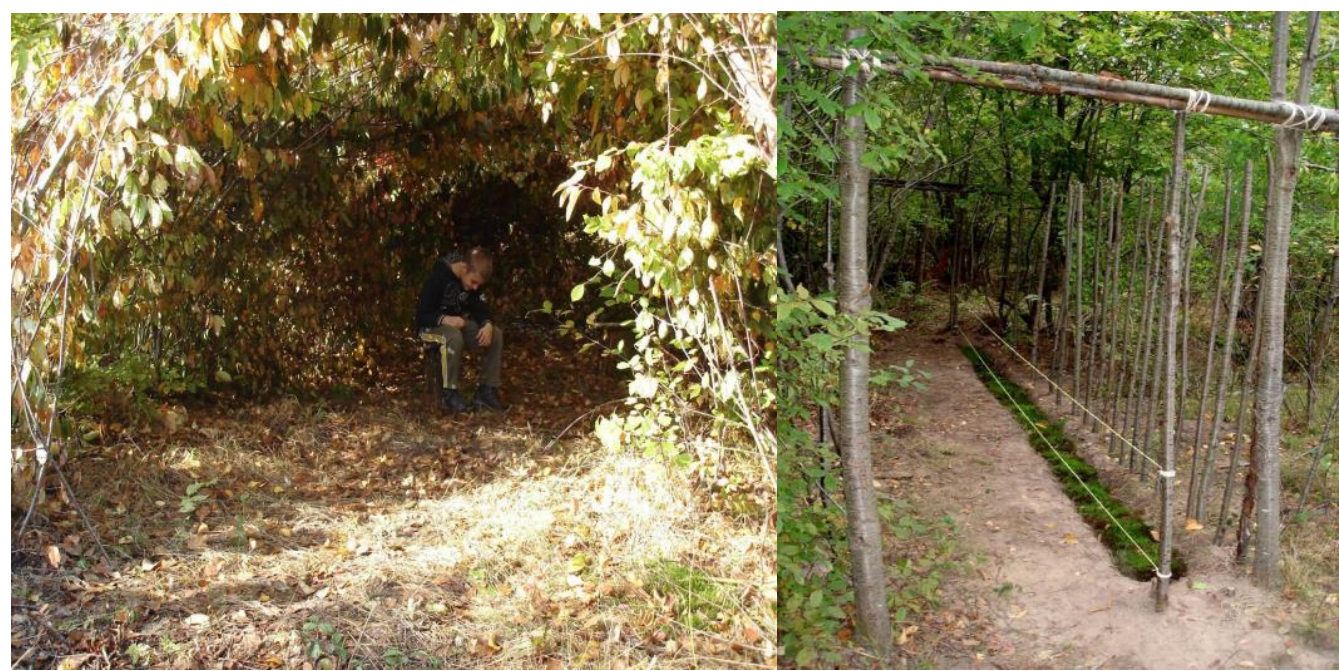

Figures 9 and 10. (left) Archetypes (right) Inventing Architecture

Source: Anke Vrijs. 


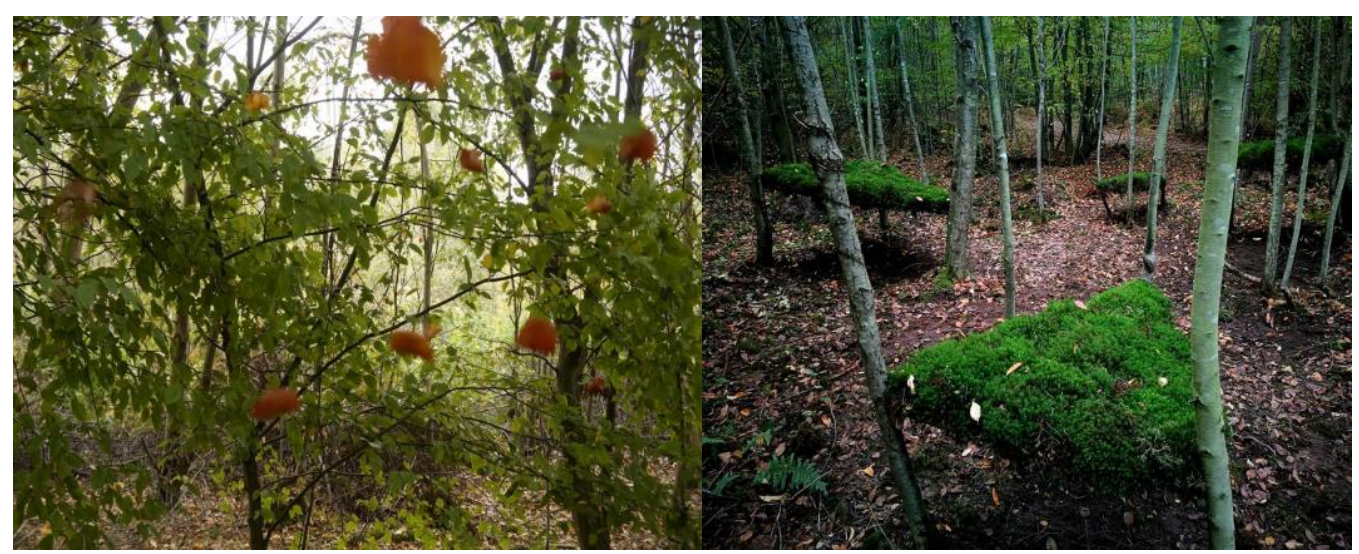

Figure 11. Examples of the Poetic Approach

Source: Anke Vrijs.

Importantly, all of these themes are closely intertwined with the site features, as they are the expression of a reaction to the place. The recurrence raised several questions: is it a result of a normative way of teaching or in contrary of the interdisciplinary approach? Also, how does one evaluate the reaction to a site? When looking at the outcomes of the poetic approach sub-category, one might think it is quite free from the site features, but is it really so?

Furthemore, since the aim was also to evaluate how much these themes are disciplinary-bound, three themes clearly are (geometry, archetypes, and inventing architecture), whilst the four others (anamorphosis, micro or macro scale, perspectives, and the poetic approach) have drawn from the landscape art discipline to different levels. As such, it can be concluded that the interdisciplinary approach had quite an influence on the student outcomes and demonstrated that the students integrated their knowledge and methods from other disciplines.

\section{Levels of Transdisciplinarity}

Experimenting on small scale objects during a very short period means being able to react and act spontaneously in terms of planning. This spontaneity though is not (only) based on intuition, but can be the result of "transdisciplinarity as a strategy to reach a certain form of unity between subjective and objective knowledge." ${ }^{19}$ Student work corroborates this statement, as do the student approaches in developing their work.

For example, assembling different elements on a drawing looks often very easy, but how does it work out in reality when two pieces of wood have to be fixed together? Two projects of seat creation express this dilemma. In the first case (2013), the drawing expresses a certain quality of comfort for the seat (Figure 12). In reality however, the backrest was badly fixed, thus preventing the seat to be truly comfortable. The students knew how a seat looks like, but did not manage to find a compromise between the simple material (wood), the limited number and type of tools they could use (hammer and saw) and the time they had to realize the object. In the second example from 2008, the photo shows a nice design, small

19. Resweber, Le Pari de la Transdisciplinarité. Vers l'Intégration des Savoirs, 2000, 48. 
twigs are regularly disposed and the seat looks very convenient (Figure 13). Yet the seat itself broke as soon as the first person tried to sit on it for the dimensions of the pieces of wood were completely underestimated. In both cases, the students learned the hard way that some specific skills are to be sought outside their disciplinary knowledge. In their case, they missed knowing the employed material which means being familiar with the weight, composition, flexibility, and resistance, for instance. They also lacked time or even understanding to look for adequate solutions to use this material and to test them before the elaboration of the final outcome.

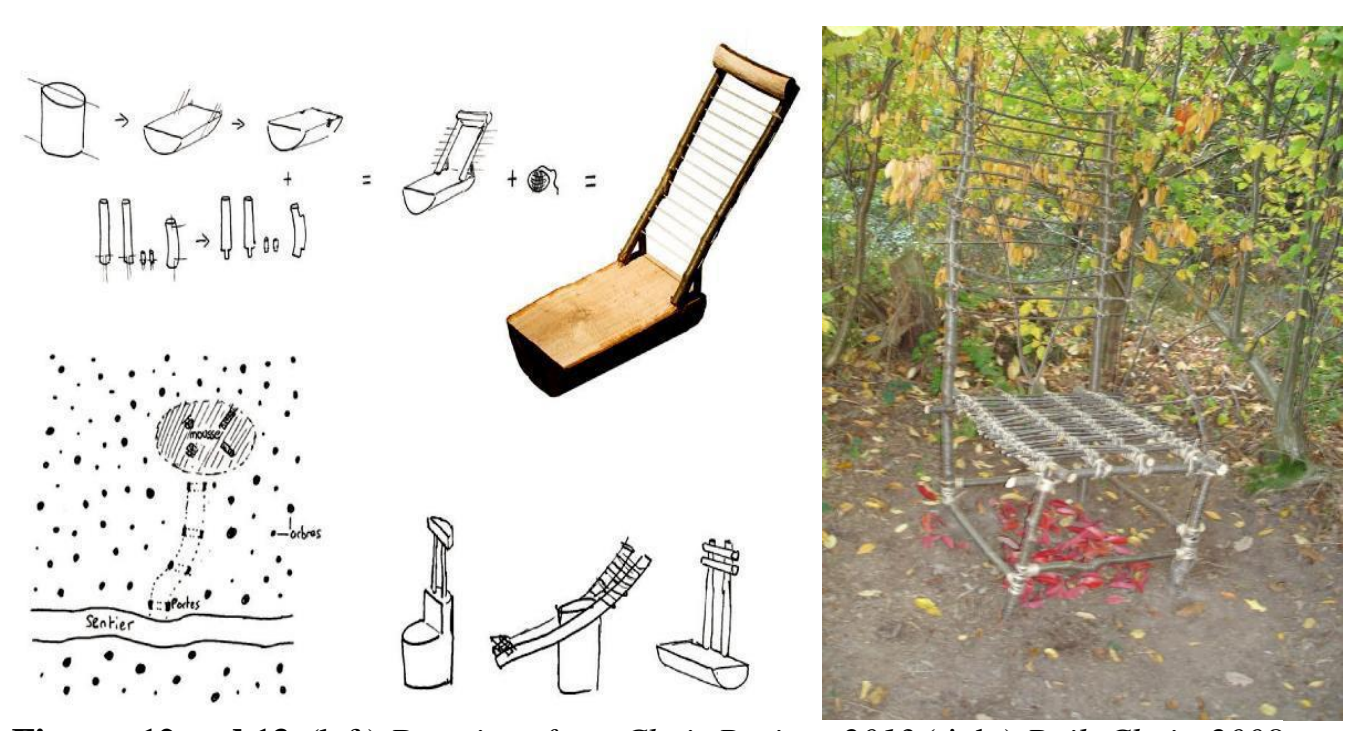

Figures 12 and 13. (left) Drawings for a Chair Project, 2013 (right) Built Chair, 2008

Source: (left) Benoît de Cillia, Camille Duval, Caroline Moroni, Rafal Kaczmarek (right) Anke Vrijs.

Secondly we propose to look at two installations dating both from 2015. One is a sort of eyepiece installed at the border of the main path in order to focus the sight on a small tree situated a couple of meters away (Figure 14). The title is "Visible mais inaccessible" (Visible without access). Small twigs are assembled by wire in an apparently chaotic way around a circle. The way this object was made seemed to be very resistant. Two years after the installation it was still perfectly hanging between the branches. The center shows up a very high density of twigs which makes the piece very resistant. The elegance is created by the geometry contrasting with the more dispersed order of the outer twigs and the surrounding trees. In terms of organisation, this work indicates a clear limit, a transparent and light limit, though impressive and solid. Here the simple material of wooden twigs shows that the flimsiness of the structure is an illusion. The way the twigs are fixed is highly sophisticated and the result of much experience. Due to the later, doing and undoing, fixing in this or that way, the students eventually managed to carry out a perfect object according to their design. 


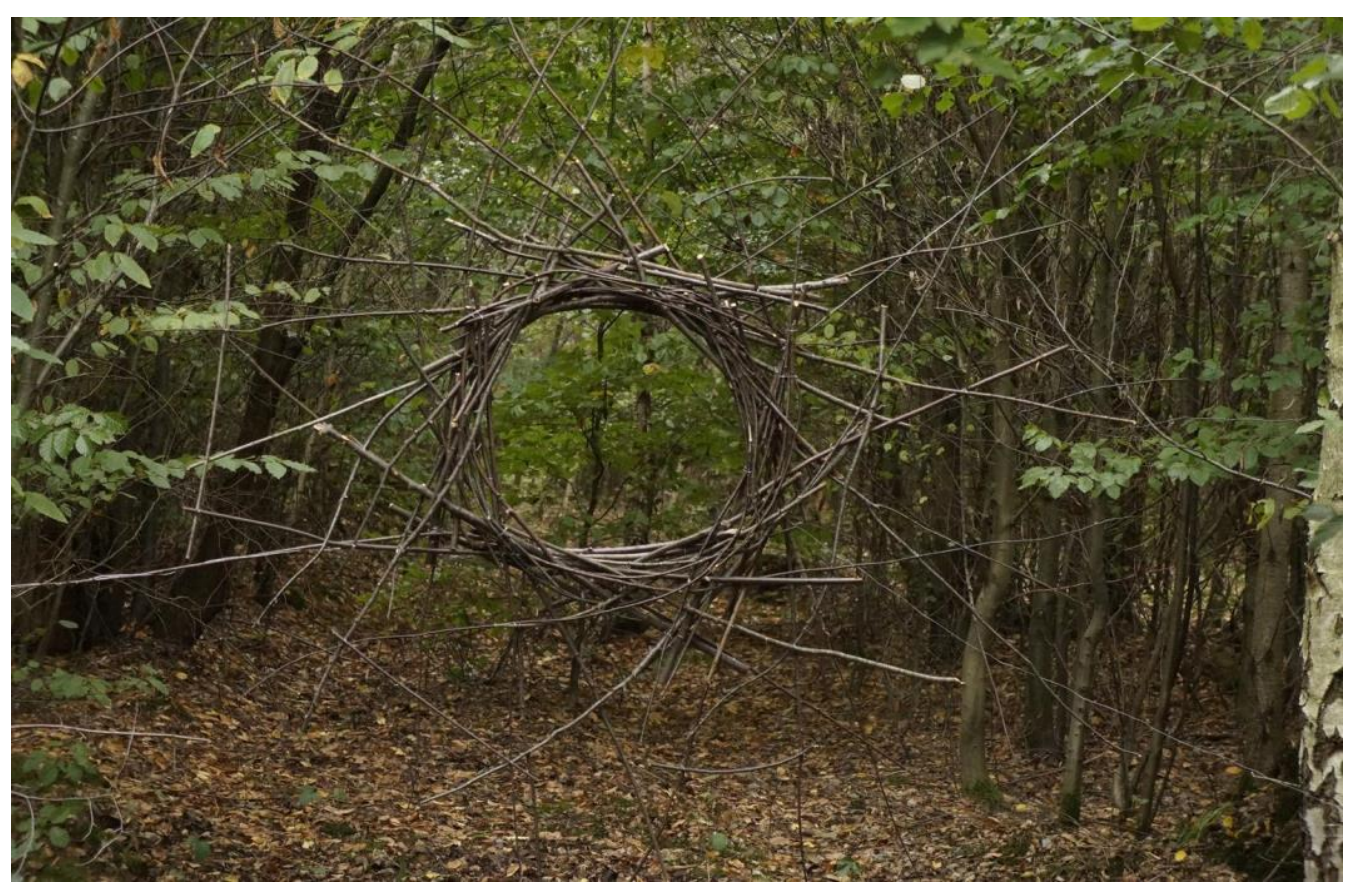

Figure 14. Installation, 2015

Source: Anke Vrijs.

The installation named "Ruban en ballade" (Travelling Ribbon), shows equivalent qualities. A simple ribbon made out of four strings crosses delicately a part of the forest. The distance in between the different strings is inspired by the width of the grey marks on the trees used by the National Forest Office to limit the different parcels of land. The idea was to introduce a simple line in the more or less chaotic forest. In this project the students acted in a clear artistic attitude drawing a long line in the forest. The difficulty was to create the impression of a very straight line. The risk was that this line would be slack and flabby because of the more or less elastic strings they intended to fix on poles grounded into the soil. As it is forbidden to put nails directly in the trees to fix the strings, the students had to imagine how they could "translate" their design into the reality of the place. They took the option for a "low tech" solution (Figure 15). They attached a piece of wood with two wires on the tree, which allowed them to fix the strings then with four nails in the piece of wood without damaging the tree. This simple solution shows the inventiveness of the four students within the many limiting factors

- Not to damage the trees.

- Working with poor and few materials.

- Having one and a half days to set up the concept, to test the fixing methods and carrying out the project. 


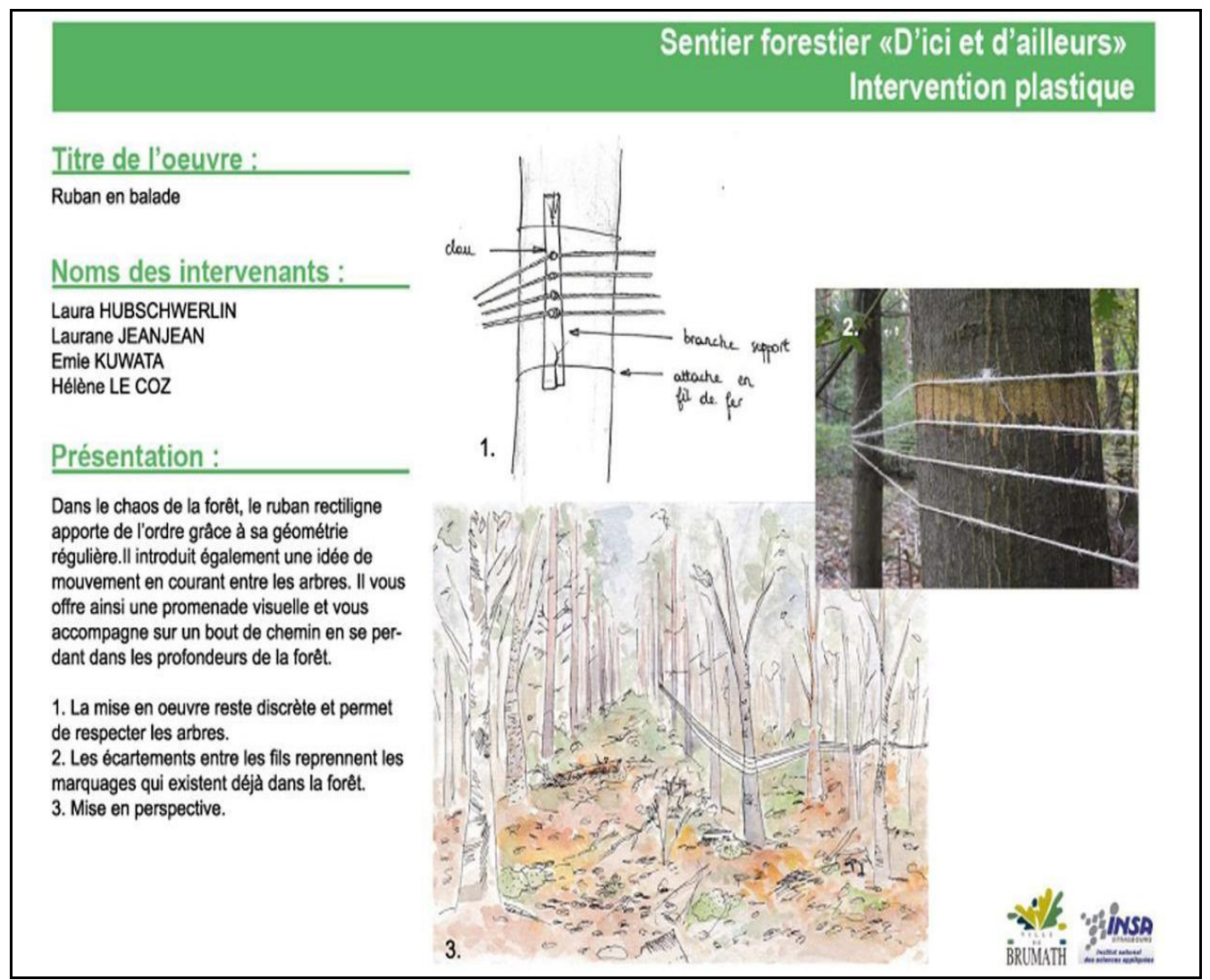

Figure 15. Example of Project, 2015

Source: Laura Hubschwerlin, Laurane Jeanjean, Emie Kuwata, Hélène Le Coz.

This set of constraints integrated by the students made them act beyond disciplinary perspectives of art and architecture, without being conscious of it in the beginning. They combined knowledge and skills, activated their problemsolving competencies and drew on their own experience to achieve a satisfying result. This is exactly what architects are supposed to implement all their life! In this case, testing the production of small scale art installations in a very short time, allowed the students to be aware of the complexity of a project and the inherent risks. Almost $100 \%$ of the students embraced the transdisciplinarity but not all of them in its entirety. Judging approximately, it could be stated that all used it at the communication stage, and $75 \%$ at the conceptualisation, design thinking and process phases. Nearly every student became aware of the importance of transdisciplinary skills, but this was in most cases the result of intense discussions with the teaching staff and critical analysis of their construction stage.

\section{Structural Changes 2008-2018}

Other changes also influenced the workshop outcomes. For example, the introduction of a specific theme from 2010 onwards refined the relationship between the site and the art installation. 'Perspective' was the first theme we chose and the results gave a more solid base to the projects (Figure 16). 


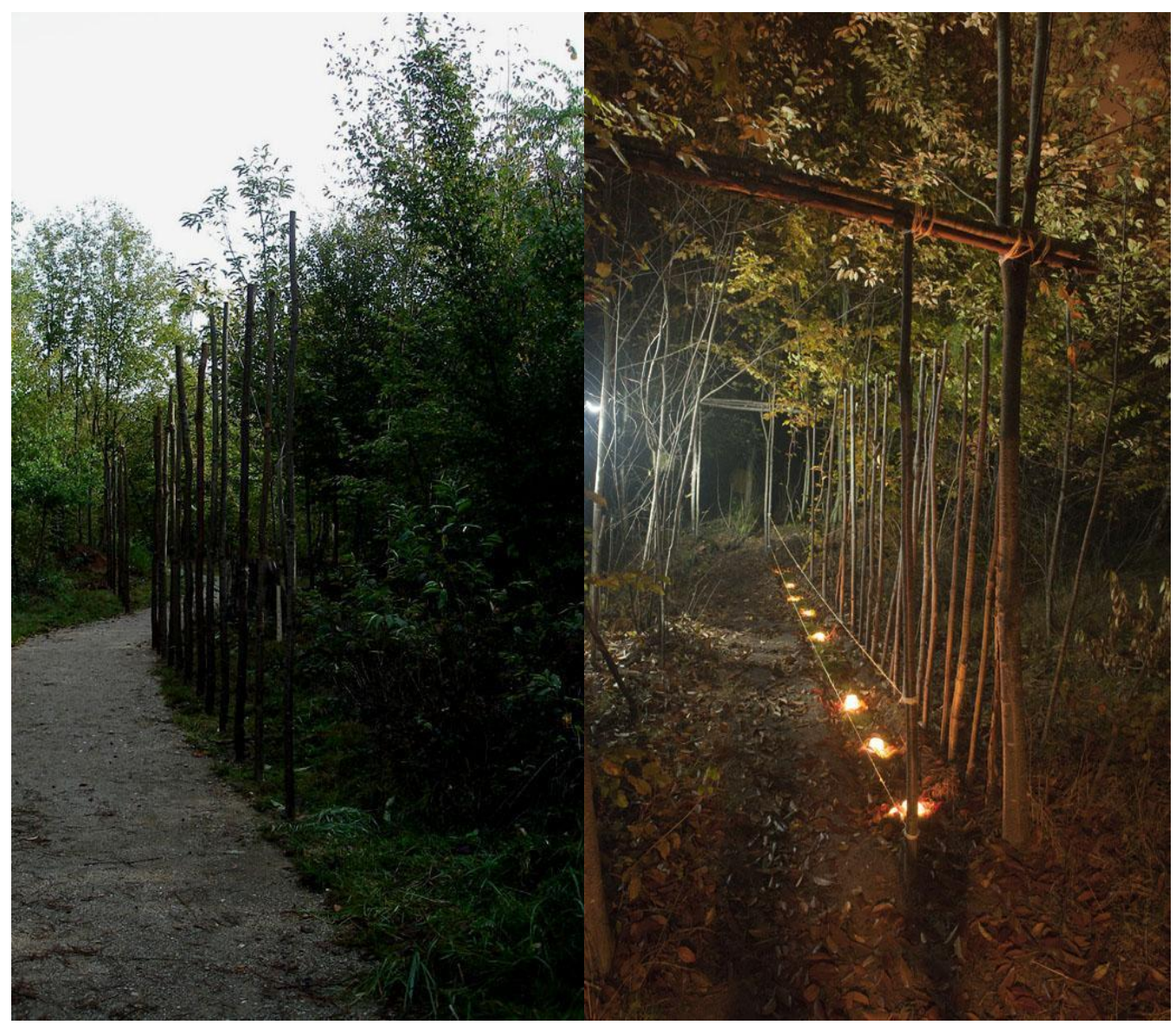

Figures 16 and 17. (left) Project, 2010 (right) Project, 2011

Source: (left) Anke Vrijs (right) Klaus Stöber

Another aspect concerns the influence of the forest's changes. In 2008, when the land art workshop started, the forest of Brumath still showed signs of the 1999 cyclone. Today, ten years later, the forest has recovered, the tree height and density have increased. The Sequoia trees still visible in 2008 for example disappeared little by little completely in the mass of the surrounding trees (Figure 18). These changes influenced the students work as the students often reacted towards the higher density of the forest by choosing dark spots within the forest to develop their projects.

In 2011 and 2012 the city of Brumath decided to organize a festival integrating the land art projects. These were illuminated during the night (Figure 17). It also transformed the way to produce and think about the art installation since it introduced the notion of a night experience.

Another important change took place in 2013 when the workshop became an integral part of the official European Architecture Days Event. This event is organised around a yearly topic that drives all their conferences and exhibitions. For example in 2013 it was 'Metamorphosis', in 2014 'Enlightened architecture', and in 2015 'Perspectives'. This enabled the students to reduce their focus and not to be too overwhelmed by the forest and, importantly, to show how rich and diverse one focus can be. The public seems to appreciate this variety around one 
unique theme, as there are more and more visitors and press coverage. Some kind of annual ritual has been instaured for which the Brumath residents are looking forward to the student works. The students' interventions not only transform the forest, but they renew the relationship between the population and this natural environment.

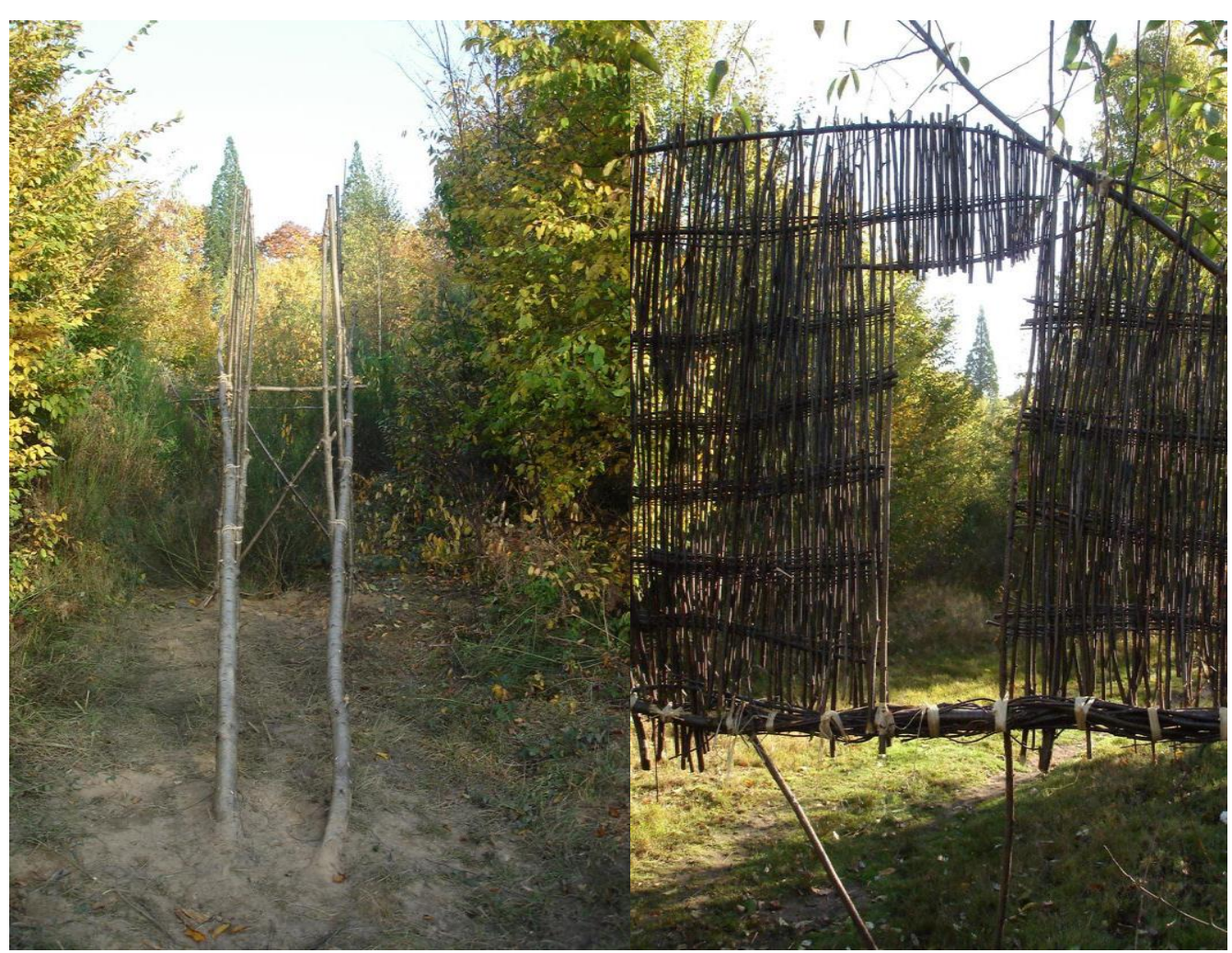

Figure 18: The Same Site at 3 Years Interval (left) 2008 and (right) 2011 Source: Anke Vrijs.

In conclusion, it is quite evident that these structural changes have impacted the outcomes, yet it did not fundamentally disturb the inter and transdisciplinary approach. On the contrary, it was exacerbated to a new dimension when community became an audience.

Overall, the analysis based on the systematic comparative review of the produced outcomes through three main criteria, shows that even if the course provided interdisciplinary skills, transdisciplinary features are not really present, unless a real critical reflection was actioned.

\section{Conclusions}

This research questioned how inter and transdisciplinary skills can be developed through experimenting and learning about the relationship between art and the natural environment. It was found that direct experience with the site 
played a crucial role to achieve this, as already discussed by Schramm (2014). ${ }^{20}$ However these physical and poetical experiences need training. The land art workshop offers this training and is not only "a fantastic playground" (to use some student wording), but above all a place to test interdisciplinary approaches on small scale installations. The main interest lays in the transferability of the process to larger scales for architectural projects.

Besides, the recurrence of topics within the produced outcomes over the tenyear period also suggests that the approach through sensory experiences, the emotions they create and our ability to connect to places are lovely poetic ideals but can become overwhelming when stepping into the making. In the same way that Christopher Alexander developed a theory on the pattern of language for the built environment (1977), ${ }^{21}$ and Tom Turner transposed it for cities, to be understood as landscapes (1986), ${ }^{22}$ students integrated knowledge and methods from different disciplines, using a real synthesis of approaches to develop their projects. This interdisciplinary approach becomes interesting when overall it leads to transdisciplinary results, creating a unity of intellectual frameworks beyond the disciplinary perspectives.

Another learning lesson concerns the fact that 'to design is not to make'. To make implies constructive imperatives which call for specific skills and competencies. All architecture students do not have necessary internships on construction worksites throughout their education and yet it seems indispensable to do so, as this research has shown. Through this land art workshop, students understood the difference between the image of the project they designed and the making of the project. Thus it raises the question whether architecture curriculum should be revised to introduce more practical knowledge.

Finally, this study has demonstrated that the place is inspiring as much as it is constraining, and there is a constant iterative process between both, ranging from emotion to rationality. Students had to find the right balance, using both what they had learnt previously, were learning and what they were experiencing. In becoming aware of the decisions they were making and the processes they were using, it was maybe the best way to enhance their interdisciplinary skills.

\section{Bibliography}

Alexander, Christopher, Sarah Ishikawa and Murray Silverstein. A Pattern Language: Towns, Buildings, Construction. Oxford: University Press, 1977.

20. Samantha Schramm, Land Art. Ortskonzepte und Mediale Vermittlung. Zwischen Site und Nonsite (Berlin: Reimer, 2014).

21. Christopher Alexander, Sarah Ishikawa and Murray Silverstein, A Pattern Language: Towns, Buildings, Construction (Oxford: University Press, 1977).

22. Tom Turner, City as landscape: A Post-Postmodern View of Design and Planning (London and New York: Taylor \& Francis, 1996). 
Atfield, Gaby and Kate Purcell. "Graduate Labour Market Supply and Demand: Final Year Students' Perceptions of the Skills they have to Offer and the Skills Employers Seek." Futuretrack Working Paper 4 (2010).

Bret, Jean-Noël and Yolaine Escande. Le Paysage, Entre Art et Nature. [Landscape, between Art and Nature.] Rennes: Presses Universitaires, 2017.

Boix Mansilla, Veronica, William C. Miller, William. C. and Howard Gardner. "On Disciplinary Lenses and Interdisciplinary Work." In Interdisciplinary Curriculum: Challenges of Implementation. Edited by S. Wineburg and P. Grossman. New York: Teachers College Press, 2000.

Dauge, Yves. Rapport d'Information Fait au Nom de la Commission des Affaires Culturelles sur les Métiers de l'Architecture. Annexe au Procès-verbal de la Séance du Sénat du 16 Novembre 2004. [Information Report on the Professions of Architecture by the Cultural Commission. Annexe of the Memorandum of the Senate Session of November 16, 2004.] http://www.senat.fr/rap/r04-064/r04-0641.pdf. [Accessed August 11, 2015].

El Hanandeh, Ali, Karine Dupré and Benoit Gilbert. "Enriching Architecture Courses with Engineering Knowledge." AAEE 2013 Proceedings (2013).

Frapier, Christel. Les Ingénieurs-Conseils dans l'Architecture en France, 1945-1975: Réseaux et Internationalisation du Savoir Technique Volume I: Texte. [AdviceEngineers for Architecture in France, 1945-1975: Network and Internationalisation in Technical Knowledge Volume I: Text.] PhD Thesis. University of Paris I, 2009.

Guêné, Franck. De l'Idée Architecturale aux Lieux de l'Architecture. L'Approche du Lieu comme Révélateur de la Nature du Regard de l'Architecture sur le Monde. [From the Architectural Idea to Architectural Place: an Approach to the Place which Reveals the Architect's Standpoint and View of the world.] PhD Thesis. Strasbourg: University of Strasbourg, 2009.

Jensenius, Alexander. Disciplinarities: Intra, Cross, Multi, Inter, Trans. http://www.arj.no/ 2012/03/12/disciplinarities-2/. [Accessed May 20, 2018.]

Klein, Julie. Interdisciplinarity: History, Theory, and Practice. Detroit: Wayne State University Press, 1990.

Lemoine, Serge. L'Art dans le Paysage du Tramway d'Orléans. [Art in the Landscape of the Tramway in Orléans.] Paris: Editions des Musées Nationaux, 2002.

Newell, William. "Decision Making in Interdisciplinary Studies." In Handbook of Decision Making. Edited by G. Morçöl. New York: CRC, 2007.

Norberg-Schulz, Christian. Genius Loci: Towards a Phenomenology of Architecture. New York: Rizzoli, 1979.

Office National des Forêts. "Introduction, Aménagement Forestier Forêt Communale de Brumath.” [Introduction, Forest Management in Brumath.] Bas-Rhin, 2014, 20132032. https://bit.ly/2QFa5po. [Accessed June 10, 2018].

Paul, Patrick and Gaston Pineau. Transdisciplinarité et Formation. [Transdisciplinarity and Education.] Paris: L'Harmattan, 2005.

Resweber, Jean-Paul. Le Pari de la Transdisciplinarité. Vers l'Intégration des Savoirs. [On Transdisciplinarity. Towards an Integration of Knowledge.] Paris: L'Harmattan, 2000.

Schaal, Hans-Dieter. Landscape as Inspiration. Berlin: Ernst \& Sohn, 1994.

Schramm, Samantha. Land Art. Ortskonzepte und Mediale Vermittlung. Zwischen Site und Nonsite. [Land Art. Concept of Places and Mediation. Between Site and Nonsite.] Berlin: Reimer, 2014.

Shannon, Susan and John Paul Swift. "Employing Graduate Attribute Mapping to Bridge the Divide from Education to Industry." Proceedings of $44^{\text {th }}$ Annual Conference of 
the Architectural Science Association, ANZASCA. Auckland, NZ: United Institute of Technology, 2010.

Spelt, Elisabeth, Harm J. A. Biemans, Hilde Tobi, Pieternel Luning and Matthijs Mulder. "Teaching and Learning in Interdisciplinary Higher Education: A Systematic Review." Education Psychology Review 21, no. 4 (2009): 365-378.

Stember, Marilyn. "Advancing the Social Sciences through the Interdisciplinary Entreprise.” The Social Science Journal 28, no. 1 (1991): 1-14.

Tapie, Guy. Les Architectes: Mutations d'une Profession. Logiques Sociales. [Architects: Changes of a Profession. Social Logics.] Paris: L'Harmattan. 2000.

Tiberghien, Gilles. Nature, Art, Paysage. [Nature, Art, Landscape.] Arles: Actes Sud, 2001. Tucker, Richard and Hisham Elkadi. "Teaching in Practice: Work Integrated Design Learning and Practice Readiness for Architecture Students." Proceedings of Association of Architecture Schools of Australasia, AASA. Melbourne, Australia, 2011, 341-354.

Turner, Tom. City as Landscape: A Post-Postmodern View of Design and Planning. London and New York: Taylor \& Francis, 1996.

Van Merriënboer, Jeroen and Getrudes Johannes. Training Complex Cognitive Skills: A Four-Component Instructional Design Model for Technical tTaining. Englewood Cliffs: Educational Technology, 1997. 
